Revista Água Viva

\title{
A PATERNIDADE ENCARCERADA A PARTIR DO RELATO FILIAL: UMA LEITURA DE PAI FRANCISCO, DE MARINA MIYAZAKI ARAÚJO
}

\section{THE IMPRISONED PATERNITY ACCORDING TO THE FILIAL NARRATION: A READING OF PAI FRANCISCO, BY MARINA MIYAZAKI ARAÚJO}

Gustavo Haiden de Lacerda ${ }^{1}$

Recebido em: 12 jul. 2019.

Aceito em: 22 nov. 2019

DOI 10.26512/aguaviva.v4i3.26162

RESUMO: Com este artigo, propomos uma leitura da obra Pai Francisco, de autoria de Marina Miyazaki Araújo (2015), dando enfoque à relação estabelecida entre pai e fillho em uma condição muito específica: o estado de reclusão narrado pela visão da criança. Guiados pela compreensão que Foucault (1999) desenvolve acerca do funcionamento da prisão em nossa sociedade e respaldados na análise de obras de literatura infantil visionada por Lajolo (2008), procuramos analisar e compreender de que modo se estrutura a relação familiar e afetiva entre um filho e um pai que se encontra encarcerado. Entendemos que a Literatura pode assumir nesse contexto um papel fundamental como forma de visibilizar relações familiares não-tradicionais, dando voz e vez a maneiras heterogêneas de ser pai e de ser filho.

Palavras-chave: Literatura infantil. Pai Francisco. Prisão. Relações familiares.

\begin{abstract}
In this article, we propose a reading of Pai Francisco, a book by Marina Miyazaki Araújo (2015), emphasizing the relationship established between father and son under a very specific condition: the state of confinement narrated by the lenses of the child. Guided by Foucault's (1999) understating of the functioning of the prison in our society and supported by Lajolo's (2008) comprehension of children's literature analysis, we analyzed how the familiar and emotional relations are structured between a son and a father who is imprisoned. We understand that Literature can take on a fundamental role in this context as a way of make non-traditional family relations visible, giving voice and place to heterogeneous forms of being a father and of being a son.
\end{abstract}

Keywords: Children's Literature. Pai Francisco. Prison. Family Relationships.

\footnotetext{
${ }^{1}$ Cursando graduação na área de Letras na Universidade Estadual de Maringá (UEM) e desenvolvendo pesquisa na área em Linguística, com aporte teórico da Análise do Discurso de linha francesa, analisando principalmente materialidades digitais. E-mail: gustavo.haiden@gmail.com
} 


\section{E a visita começa...}

A presença da criança como um constituinte essencial dentro de uma formação social é tema recorrente na Literatura infantil contemporânea, e mostra a importância da infância no processo de edificação de habilidades sócio emocionais. Conforme Aguiar (2011, p. 51), “é escusado salientar a importância da leitura literária como experiência imprescindível para o desenvolvimento emocional, cognitivo e social do indivíduo". Com isso em mente, propomos aqui uma leitura de Pai Francisco, de Marina Miyazaki Araújo, com ilustrações de Marcus Vinícius Vasconcelos, que narra, pela voz da própria personagem infantil, as angústias e os anseios de um filho que sente a falta do pai, que se encontra preso.

Este trabalho discute uma relação familiar muito particular, especificamente entre pai e filho, que, mesmo peculiar, é comum a muitas famílias brasileiras. Nesse sentido, entendemos que é relevante dar destaque aos modos como esse vínculo familiar se mantém (ou não) mesmo que o pai encontre-se em situação de cárcere. Nosso objetivo é refletir sobre os modos com que a literatura - aqui a infantil - pode favorecer a experiência de ser filho de um pai aprisionado com uma escuta atenta e sensível, além de apontar para formas heterogêneas e possíveis de se viver em família.

A primeira seção apresenta um breve panorama da Literatura infantil atual, na tentativa de esboçar o contexto de produção da própria obra trazida para análise. Nesta mesma parte, trazemos algumas informações e comentários sobre a criação artístico-literária de Araújo e de Vasconcelos, como forma de reforçar as condições de produção de Pai Francisco.

Afunilando a temática, na seção seguinte, descrevemos a maneira como a Lei encara e regula os direitos de relacionamento familiar em contexto de cárcere. Com isso, explicamos qual é a maneira com que se concebe o significado de estar preso, de ser pai enquanto se está em reclusão e de ser filho de um pai preso, e de que forma a literatura infantil pode contribuir com essa discussão.

Em um terceiro e último momento, analisaremos mais detidamente a obra em questão, dando enfoque à relação entre pais e filhos, pensando em que medida o cárcere afeta o convívio familiar e até mesmo o desenvolvimento sócio emocional da criança. Nossa leitura buscou dar visibilidade também à relação entre o texto verbal e o imagético, que estabelecem um vínculo enunciativo muito estreito, particularmente na obra de literatura infantil, de maneira a incitar interpretações críticas e plurais. 
O presente artigo constitui-se, portanto, como uma breve visita a este filho sem nome, representante de tantos filhos, que deseja o convívio do pai, um Francisco entre tantos outros. A leitura direciona-se a partir da constatação de que a prisão do pai pode trazer consequências para a vida (liberdade?) dos filhos, o que nos convoca a prestar atenção a um lado de uma história que, na maioria das vezes, não é contado.

\section{Literatura infantil: histórico e perspectivas}

Com o advento dos ideais iluministas, durante os séculos XVII e XVIII, inicia-se um processo de construção do que significa ser criança. Naquele contexto, a infância era compreendida como um período intermediário para a vida adulta, o que apontava para a necessidade de formar a criança para vir a ser um bom cidadão. A Literatura infantil oriunda desta época nasce, então, com um olhar pedagógico, almejando a instrução e educação das crianças. Conforme Aguiar (2011), esta literatura infantil inicial é marcadamente mediada pelo olhar adulto, que cerceia e manipula comportamentos, com propósitos educativos e moralistas.

Durante seu desenvolvimento, a literatura destinada a crianças encontrou forte sustentação dentro do espaço escolar, responsável pela divulgação de materiais produzidos com os fins pedagogizantes mencionados acima. Aguiar (2011) explica que, ao organizar-se enquanto instituição pública e para todos, a escola impulsiona também o mercado de produtos culturais, tornando-se alvo e espaço de circulação da produção de obras de literatura infantil. Aliando à escola, o texto literário passa a transmitir certos valores sociais e a "criar modelos satisfatórios que, uma vez absorvidos pelo leitor, venham a torná-lo um adulto adaptado ao meio em que vive" (AGUIAR, 2011, p. 52), barrando as possibilidades de uma literatura preocupada com a emancipação da criança.

Entretanto, com o avanço de teorias que enxergavam já na criança uma subjetividade como os estudos de Freud sobre o infantil na sua relação com o inconsciente, ou a teoria de Piaget acerca dos estágios de desenvolvimento e aprendizagem, ou ainda os movimentos artísticoculturais revolucionários do Modernismo - a Literatura infantil começa a tomar um rumo diferente, assumindo papel formativo diferente daquele pedagogizante. Entendendo a importância da infância na vida de um indivíduo, a literatura assume uma função essencial: fomentar a imaginação. A ficção se estabelece aí como forma de lidar com a realidade, modalizá-la, trabalhála, interpretá-la, para vivê-la de maneira mais completa, uma vez que, "quando se compromete com o interesse da criança ou do jovem, transforma-se em meio de acesso real" (AGUIAR, 2011, 
p. 53). Mesmo isenta de compromissos com a realidade, a atividade literária não perde de vista suas conexões com ela.

Outra função que intensifica a relevância da literatura infantil é a forma lúdica com que apresenta ao pequeno leitor diferentes maneiras de encarar e compreender o mundo à sua volta, ressignificando experiências cotidianas a partir do olhar encantado e explorador familiar à criança. Lajolo (2008) enfatiza que o papel da literatura é, portanto, notoriamente social, pois retrata e afeta positivamente as vivências e leituras de mundo das crianças.

É à literatura, como linguagem e como instituição, que se confiam a diferentes imaginários, as diferentes sensibilidades, valores e comportamentos através dos quais uma sociedade expressa e discute, simbolicamente, seus impasses, seus desejos, suas utopias. Por isso, a literatura é importante no currículo escolar: o cidadão, para exercer plenamente sua cidadania, precisa apossar-se da linguagem literária, alfabetizar-se nela, tornar-se seu usuário competente, mesmo que nunca vá escrever um livro: mas porque precisa ter muitos (LAJOLO, 2008, p. 106).

Indo além, a literatura infantil tem a capacidade de não só representar a(s) realidade(s), mas também de intervir de volta, possibilitando mudanças em visões de mundo e mesmo preconceitos enraizados historicamente. Como explica Lajolo (2008), a literatura tem uma força transformadora, capaz de ressignificar as relações sociais e experiências subjetivas. Reforçando ou alterando valores e imaginários sociais, a literatura infantil pode construir novas imagens sociais e dar espaço a diferentes maneiras de ser. Desse modo, "em movimento de ajustes sutis e constantes, a literatura tanto gera comportamentos, sentimentos e atitudes, quanto, prevendo-os, dirige-os, reforça-os, matiza-os, atenua-os; pode revertê-los, alterá-los” (LAJOLO, 2008, p. 27).

Uma última função da literatura infantil que merece destaque é apontada por Martha (2011), ao sustentar que a literatura destinada a crianças tem ainda a função de oferecer condições para o leitor expandir seus conhecimentos enciclopédicos, sociais, culturais e psicológicos, além de abrir a visão da criança para diferentes realidades e vivências distintas das que ela vive/conhece, de modo que os leitores possam "compreender os papeis que nele [no mundo] desempenham" (MARTHA, 2011, p. 22). Dito de outra forma, a literatura infantil pode encorajar o exercício da empatia, donde seu efeito humanizador.

Em conjunto, todas essas características e papeis desempenhados pela literatura voltada à infância resultam em um trabalho em prol da autonomia da criança, seja social ou emocionalmente. Tal emancipação se produz justamente porque a literatura pode tem um poder (trans)formador. Para tomar as palavras de Costa (2011), 
Pode-se concluir que a literatura brasileira destinada às crianças adquiriu, com o passar dos anos, uma dimensão artística e tornou-se um instrumento preocupado, de uma maneira geral, com a formação intelectual e afetiva dos jovens leitores. Aliado a isso, nota-se o crescente interesse de muitos autores e de alguns editores em apresentar obras literárias de qualidade em tosos os sentidos, em especial quanto ao conteúdo e à linguagem em que se expressa (COSTA, 2011, 108).

Adentrando nas produções literárias infantis contemporâneas, Martha (2011) pontua novas temáticas que passam a inspirar a escrita de obras, assuntos considerados até então tabus para a infância, e mesmo temas de maior profundidade psicológica e qualidade estética. Entram nesse novo nicho, livros que contemplam histórias folclóricas nacionais, dilemas internos, narrativas de denúncia, entre outros. Ainda segundo Martha (2011, p. 124),

Com linguagem questionadora de convenções e normas, técnicas mais complexas de narrar, as obras contemporâneas tratam de assuntos anteriormente proibidos a leitores mais jovens - morte, separação, violência, crise de identidade, escolhas, relacionamentos, perdas, sexualidade, afetividade.

Como afirma Lajolo (2008), para realizar uma análise desse tipo de texto literário voltado à infância, atualmente denso e multifacetado, devemos inscrever-nos no cotidiano da criança. A leitura deve ser guiada pelo modo com que a condição (cognitiva, social e cultural) da criança está representada e funcionando na obra, sem perder de vista a qualidade estética e a profundidade temática presente. Literatura infantil e qualidade estética não são elementos de modo algum em contradição; pelo contrário, menosprezar a literatura infantil como uma literatura menor é desconsiderar (e rebaixar) a subjetividade infantil ali construída. Nas palavras da autora, "lê-se para entender o mundo, para viver melhor (...) quanto mais abrangente a concepção de mundo e de vida, mais intensamente se lê, numa espiral quase sem fim, que pode e deve começar na escola, mas, não pode (nem costuma) encerrar-se nela" (LAJOLO, 2008, p. 4), de maneira que o ato de ler também esteja significado pelo olhar infantil e por suas experiências correspondentes, e não apenas "contaminado" pela leitura impositiva do adulto e da Escola.

Agora, pensando mais precisamente na construção de obra literárias para os jovens leitores, frisamos a importância da relação entre texto verbal e visual. Como salienta Camargo (1995), uma obra de literatura infantil deve procurar conciliar palavra e imagem, explorando variadas potencialidades de sentido dentro de uma mesma história. No livro infantil, a imagem não deve servir (nem ser vista) como uma decoração vazia ou um preenchimento despropositado de páginas; na verdade, "a ilustração pode comunicar um sentimento, uma emoção", de tal forma que "através 
de movimentos e expressões faciais de personagens, e pelos recursos gráficos" (CAMARGO, 1995, p. 36), entre outros recursos, consiga fornecer significados plurais.

Em outras palavras, todo o texto é significante, seja ele verbal, imagético, audiovisual, tátil etc. E todas as diferentes formas significantes têm um papel a contribuir na leitura e interpretação da obra. Isso aponta para um trabalho de análise que também não perca de vista a importância da imagem na produção de sentido do texto literário. A imagem, entendida como texto, oferece condições para que a leitura expanda-se, aprofunde-se e surpreenda-nos.

O livro de imagem não é um mero livrinho para crianças que não sabem ler. Segundo a experiência de vida de cada um e das perguntas que cada leitor faz às imagens, ele pode se tornar o ponto de partida de muitas leituras, que podem significar um alargamento do campo de consciência: de nós mesmos, de nosso meio, de nossa cultura e do entrelaçamento da nossa com outras culturas, no tempo e no espaço (CAMARGO, 1995, p. 79).

Tendo em vista a imersão da criança em um mundo atualmente influenciado fortemente pela experiência digital, aquela se encontra exposta a uma profusão de textos, formas, letras, cores, tamanhos, sons (multimodalidades), tudo isso em um mesmo instante, no espaço de uma tela de celular, por exemplo. Nessas condições, Camargo (1995, p. 79) afirma que "a alfabetização² não pode se restringir ao alfabeto, às primeiras letras". Por ser fruto também das condições sócio históricas em que se desenvolvem, diríamos que é preciso que as produções literárias voltadas à infância não percam de vista o leitor virtual a que se destinam, aprimorando-se no sentido de incorporar com valor estético os muitos materiais significantes que fazem parte das linguagens com as quais o jovem leitor contemporâneo está acostumado a manejar, o qual está à espera de interagir com uma literatura também ela multimodal.

Em se tratando de Pai Francisco, buscaremos dar consequência a isso nas análises, interpretando tanto a produção verbal quanto as ilustrações. Marina Miyazaki Araújo, autora da obra, é a responsável pelo texto escrito. Cursou duas faculdades e realizou uma pós-graduação que, como ela mesma diz, "nunca usou para nada". A escritora possui um grau baixo de dislexia, que é temática de outro livro de sua autoria, Dislexicalizando, no qual retrata as vivências de uma personagem criança também disléxica. Entrevistada pela Folha de São Paulo sobre a obra Pai Francisco, Araújo comenta que a escolha pelo tema delicado, de um filho que sofre com a ausência do pai detento, foi guiada pelo desejo de dar escuta a uma história pouco ouvida, de pessoas que

\footnotetext{
${ }^{2}$ Aqui cabe ler letramento.
} 
"sofrem tanto preconceito quanto a pessoa que está cumprindo a pena”3. Já o responsável pelas ilustrações foi Marcus Vinicius Vasconcelos, que além de ilustrador, é roteirista e diretor. Formado em Publicidade e Propaganda, Marcus é sócio e diretor da Teremim, empresa de produção de vídeos de animação. No seu currículo estão produções para publicidade, televisão e cinema, pelas quais angariou vários prêmios, nacionais e internacionais.

Em Pai Francisco, escritora e ilustrador, juntos, dão matéria a uma história que se constitui pela imbricação verbo-visual. A imagem não está ali somente como representação da história narrada por escrito, mas é capaz de contar sua própria história. O texto visual narra conjuntamente e paralelamente, oferecendo complementação, o que não quer dizer que se trate de uma questão de mera soma, mas de perturbação e interferência, explorando zonas de sentido próprias a cada meio semiótico. Na obra em análise, veremos que é inclusive uma imagem a responsável pela conclusão da narrativa.

\section{Corpos reclusos: sobre o sistema penal e a relação pais-filhos}

Agora, buscaremos precisar a temática a partir da qual se constrói a narrativa de Pai Francisco: o contexto prisional e seu impacto nas relações familiares. Conforme dados do Departamento Penitenciário Nacional (DEPEN, 2016), em 2016, havia cerca de 720 mil indivíduos encarcerados no Brasil, sendo que destes, mais de 90\% são homens (665.482), dos quais $47 \%$ possuem filhos. Para cada 100 mil habitantes, há em média 350 presos. Portanto, o Brasil assume posição de destaque entre os países com a maior quantidade de população carcerária mundial, ficando atrás somente dos Estados Unidos (2,2 milhões) e da China (1,7 milhão).

A partir de seus estudos, Granja et al. (2013) relatam que, das poucas pesquisas que se ocupam da questão da parentalidade em contexto de reclusão, a maioria dá enfoque à maneira como a maternidade é afetada pelo cárcere. Segundo os autores, o tópico "paternidade reclusa" praticamente não consiste em pauta para o Sistema Penal. Ainda nas palavras dos pesquisadores, tal atitude (ou ausência dela) apenas insiste na ideia de que cabe às mulheres o cuidado do bemestar dos filhos, reforçando estereótipos de gênero.

Miranda e Granato (2016) chamam a atenção ao fato de que o encarceramento não produz efeitos somente para o presidiário, mas atinge também seus familiares, que sofrem conjuntamente mesmo sem terem cometido crime algum. Para as autoras, "o estigma social sofrido por toda a

\footnotetext{
3 Disponível em: https://m.folha.uol.com.br/folhinha/2015/09/1686444-em-livro-autora-aborda-relacao-delicadaente-um-filho-e-seu-pai-detento.shtml. Acesso em 21 jun. 2019.
} 
família, especialmente pelos filhos, acarreta muitas vezes sentimentos de vergonha e negação do vínculo familiar com o prisioneiro", acrescentando que "o indivíduo que se relaciona socialmente com um estigmatizado, tende a ser considerado como sua extensão, compartilhando de seu descrédito" (MIRANDA e GRANATO, 2016, p. 311).

Perpassam entre os indivíduos aprisionados sentimentos de culpa, impotência, vergonha e, inclusive, sintomas de depressão (MIRANDA e GRANATO, 2016). Essas são sobrepenas que resultam da sentença de reclusão, constituindo privações de diversas ordens, além da privação da liberdade. E uma dessas “sobrepenas” é a separação do convívio dos filhos.

Uma das maneiras de atenuar a separação familiar é por meio das visitas. Pela Lei de Execução Penal, fica explícito, no artigo 41, décimo parágrafo (Lei no. 7.210, de 11 de julho de 1984), que entre os direitos do preso está a "visita do cônjuge, da companheira, de parentes e amigos em dias determinados" (BRASIL, 1984). Além disso, na mesma lei, pelo artigo 103, fica especificado que cada comarca possuirá "pelo menos 1 (uma) cadeia pública a fim de resguardar o interesse da Administração da Justiça Criminal e a permanência do preso em local próximo ao seu meio social e familiar" (BRASIL, 1984). Ao encontro do que foi promulgado pela Lei de Execução Penal, o ECA (Estatuto da Criança e do Adolescente) reforça, em seu artigo 19, parágrafo quarto (Lei no 8.069, de 13 de julho de 1990), que

Será garantida a convivência da criança e do adolescente com a mãe ou o pai privado de liberdade, por meio de visitas periódicas promovidas pelo responsável ou, nas hipóteses de acolhimento institucional, pela entidade responsável, independentemente de autorização judicial (BRASIL, 1990).

É válido ressaltar mais uma vez que não consta nenhuma lei que especifique com mais profundidade ou que garanta com precisão o direito do convívio familiar. O pouco que se constata refere-se aos direitos de mães, sob determinadas exigências, nos casos de amamentação e gravidez, por exemplo.

A partir disso, Miranda e Granato (2016) argumentam que, pela coleta de relatos de pais reclusos, fica evidente a importância dos filhos no processo de reintegração social dos detentos, atuando como sólidos suportes emocionais, mesmo sem que as crianças saibam disso. Aliás, alguns detentos relataram que preferiam que os familiares não contassem aos filhos que eles estavam presos. Quase em unanimidade, todos afirmavam que as visitas da família forneciam-lhes um importante suporte emocional. Entretanto, frisamos que, entre os relatos coletados por Miranda e Granato (2016), houve alguns que se posicionaram contra as visitas dos filhos às penitenciárias, por entenderem que o local não era saudável para as crianças. Nas palavras das autoras (2016, p 
313), "alguns presos optam pelo afastamento dos filhos do espaço prisional como forma de cuidado e proteção". As entrevistas realizadas pelas pesquisadoras mostraram que

muitos participantes percebiam o ambiente carcerário como inerentemente hostil a crianças e adolescentes, preferindo desencorajar as visitas, com o objetivo de evitar a exposição dos filhos a situações de risco, especialmente no que se refere ao impacto emocional. Um dos pais participantes do nosso estudo recordou a experiência de, ainda criança, ter acompanhado a mãe em uma visita ao irmão que estava preso. Concluiu que aquelas imagens o marcaram profundamente: 'Não quero isso para o meu filho. O ambiente é opressor... Pode gerar traumas na criança.' (Pedro, Grupo B) (MIRANDA e GRANATO, 2016, p. 313).

O que se percebe é uma sobreposição de vulnerabilidades, tanto dos presos quanto das famílias, de modo geral, e dos filhos, de maneira especial. Nessa esteira, pensando o complexo de vulnerabilidades em jogo, Foucault (1999) lança luz sobre o funcionamento do sistema carcerário moderno. De acordo com o autor, o sistema penal moderno, iniciado no século XVIII e aprimorado no século XIX, baseia-se sobre a detenção. Nesse contexto, a detenção vem operar não como "uma resposta a uma infração, mas [para] corrigir os indivíduos ao nível de seus comportamentos, de suas atitudes, de suas disposições, do perigo que apresentam, das virtualidades possíveis" (FOUCAULT, 2005, p. 99).

Foucault (1999) chama a atenção ao fato de que não está em questão apenas uma forma de exercer punição por parte da "justiça", mas entende que há ali a interferência complacente de um poder judiciário com autonomia, uma forma de exercício desse mesmo poder, fazendo a prisão emergir como uma questão socioeconômica. De uma perspectiva como a de Foucault (1999), o sistema de prisões caracteriza-se por um conjunto de práticas (institucionais, legais, científicas, arquitetônicas, sociais) que instituem um discurso de correção, que produzem certos mecanismos de exercício prisional, como a detenção, o isolamento, a violência. E suas formas de aplicação resultam em consequências não só aos presos, mas àqueles ligados a eles, seja por meio de preconceitos por parte da sociedade, seja por efeitos mais diretos, em nível de dependência financeira e emocional; justamente o ponto contraditório em que o sistema penitenciário tropeça e fracassa.

Enfim a prisão fabrica indiretamente delinqüentes, ao fazer cair na miséria a família do detento: 'A mesma ordem que manda para a prisão o chefe de família reduz cada dia a mãe à penúria, os filhos ao abandono, a família inteira à vagabundagem e à mendicância. Sob esse ponto de vista o crime ameaça prolongar-se' (FOUCAULT, 1999, p. 295). 
O consenso social em torno do que significa ser "delinquente", lembra Foucault (1999), é determinado sobremaneira pela relação com a classe social à qual pertence o indivíduo trazido a julgamento. Segundo o autor, um delito cometido por uma pessoa pertencente a um grupo detentor de poder é visto frequentemente com "indulgência" por tribunais e autoridades no geral, haja vista que muitos deles (grupos de poder) são os responsáveis pela elaboração e aplicação dessas leis. O que a interpretação foucaultiana revela é que, do ponto de vista do poder, não se trata somente da natureza acusável de um crime, mas de jogos de força que encaminham o rico ao poder e o pobre à prisão.

Se, de um lado, coloca-se a prisão como questão de classe social, fundamentalmente destinada a uma camada (em)pobre(cida) da população, por outro, a mesma prisão funciona também como modelo institucional e disciplinar, gerador de costumes punitivos e controladores. Para Foucault (2005), o efeito disciplinar da prisão escapa das grades e muros e impregna outras instituições sociais, particularmente a família e a escola, estipulando comportamentos "normais", ou melhor, normalizados.

[as] instituições que vão enquadrar os indivíduos ao longo de sua existência; instituições pedagógicas como a escola, psicológicas ou psiquiátricas como o hospital, o asilo, a polícia, etc. Toda essa rede de poder que não é judiciário deve desempenhar uma das funções que a justiça se atribui neste momento: função não mais de punir as infrações dos indivíduos, mas de corrigir suas virtualidades (FOUCAULT, 2005, p. 86)

Refletindo sobre as visitas aos presos, o filósofo francês relembra que era uma prática muito comum as pessoas irem literalmente assistir às prisões como forma de entretenimento, como se fazia também com os hospitais psiquiátricos. Há que se pensar, então, em um efeito institucional da visitação aos presos. Ou melhor, em uma motivação institucional que dá respaldo a esse direito. De acordo com Foucault (1999), o ato de visitar as prisões (e os manicômios) servia como forma também de instruir a população, instigando o medo sobre as consequências de seus atos.

Bem antes de ser concebido como objeto de ciência, pensa-se no criminoso como elemento de instrução. Depois da visita de caridade para partilhar do sofrimento dos prisioneiros - o século XVII a inventara ou restabelecera - pensou-se nessas visitas de crianças que viriam aprender como a justiça da lei vem se aplicar ao crime: lição viva no museu da ordem (FOUCAULT, 1999, p. 131, grifo nosso).

Particularmente, no que tange à convivência entre filhos e pais aprisionados, acrescentaríamos que ocorre um fenômeno de atravessamento (como um corte) por parte do 
sistema penal sobre os relacionamentos familiares e afetivos, como uma "presença ausente" que produz sentidos sobre essas relações. Atentando-se para as situações de visita, isso poderia ser exemplificado pelas exigências legais que regulam as visitações. Consoante Foucault (2005), descrevendo o panopticon ${ }^{4}$, a prisão é o grande exemplo da "sociedade de vigilância", que deseja manter a ordem (normal) a partir de um olhar vigilante "permanente sobre os indivíduos por alguém que exerce sobre eles um poder (...) e que, enquanto exerce esse poder, tem a possibilidade tanto de vigiar quanto de construir, sobre aquele que vigia, a respeito deles, um saber" (FOUCAULT, 2005, p. 88).

O que veremos em Pai Francisco é justamente como esse "saber" consensual a respeito de pais presos, que é predominantemente de que estes são indiferentes aos próprios filhos, não necessariamente representa a realidade de relações afetivas muito heterogêneas. Acreditamos que o que a Literatura Infantil tem a contribuir nesse debate está em desconstruir esses preconceitos enraizados, dando visibilidade, por exemplo, a múltiplas formas legítimas de se viver em família. Tal perspectiva é adotada e explicada com maestria pela própria autora de Pai Francisco, expondo sucintamente toda a proposta da história construída, ao escrever poeticamente na "orelha" do livro: "Um pai real, um pai imaginário / um pai do mal, um pai do bem / Todos habitam o mesmo pai".

\section{A paternidade encarcerada na visão do filho: visitando Pai Francisco}

A primeira coisa que merece atenção é a capa do livro (figura 1). Nela, está registrado o momento de encontro do filho com o pai, abraçados, presos um ao outro. O mesmo abraço é retomado durante a narrativa, na página treze ${ }^{5}$, reiterando que este é o ápice da história. $O$ primeiro contato que temos com as personagens, por meio da ilustração na capa, é uma cena de carinho e intimidade, redimensionando o imaginário que se tem acerca da relação afetiva que pais detentos mantêm com seus filhos, efeito transformador muito peculiar à literatura infantil, como ressaltado por Lajolo (2008). De fato, esse abraço joga justamente contra um imaginário de que um pai, por estar preso, não pode ter um bom relacionamento com os filhos, e vice-versa.

\footnotetext{
${ }^{4}$ Em Foucault, o "panopticon" faz referência ao sistema penal, mas também à "Sociedade de vigilância" de um modo geral, como "um edifício em forma de anel, no meio do qual havia um pátio com uma torre no centro. $\mathrm{O}$ anel se dividia em pequenas celas que davam tanto para o interior quanto para o exterior [...] $\mathrm{Na}$ torre central havia um vigilante [...] que observava através de venezianas, de postigos semi-cerrados de modo a poder ver tudo sem que ninguém ao contrário pudesse vê-lo" (FOUCAULT, 2005, p. 87).

${ }^{5}$ Mesmo o livro não contendo numeração nas páginas, optamos por numerá-las aqui na sequência da encadernação, como forma de garantir o encadeamento e a organização das análises.
} 


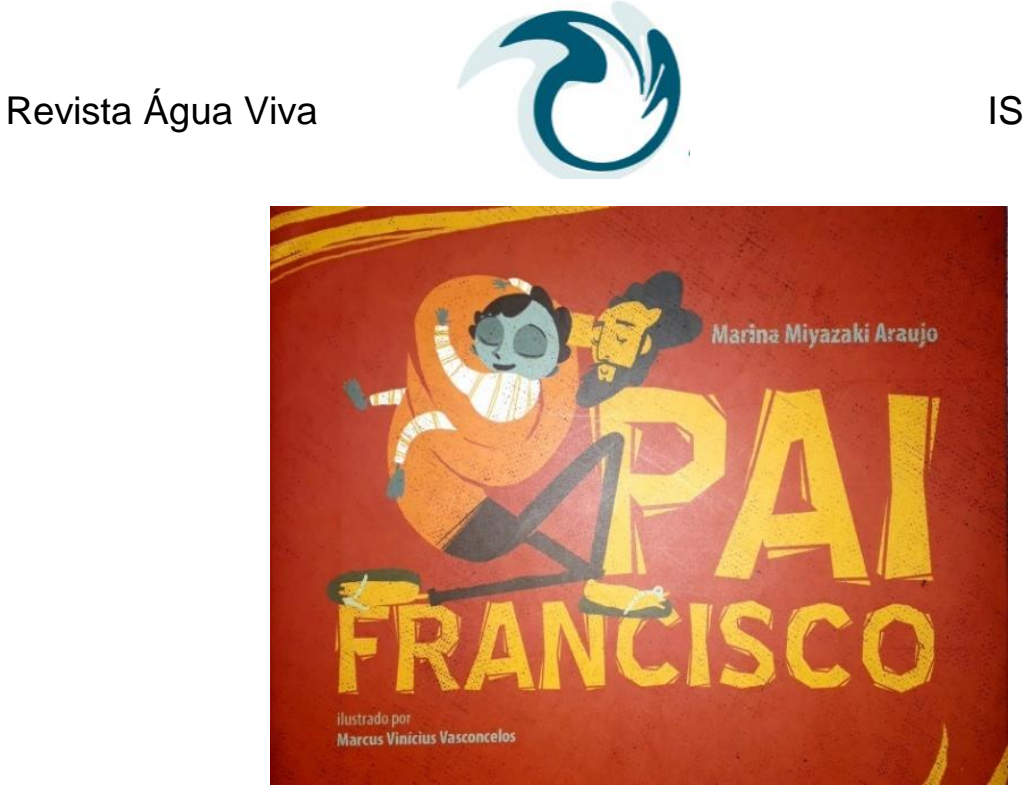

Figura 1 - Capa de Pai Francisco

Ainda antes da narração, uma epígrafe, abaixo da imagem de um violão (figura 2) cujas cordas estão arrebentadas: "Pai Francisco entrou na roda tocando / o seu violão dororón dondón / Vem de lá Seo Delegado / e Pai Francisco foi pra prisão" (ARAÚJO, 2015, p. 3). Este é um trecho de uma cantiga do folclore brasileiro, comum entre as canções infantis, que conta brevemente o episódio em que um homem, Pai Francisco, foi preso enquanto tocava seu violão. Não são apresentados os motivos de sua prisão; ele apenas foi levado pelo delegado. Também em Pai Francisco o leitor não fica sabendo o motivo que levou o pai à prisão, atualizando a canção popular. Segundo Aguiar (2011), quando a literatura infantil retoma tradições orais, folclóricas e históricas do Brasil, "questionam-se as mazelas sociais, buscando-se as intenções que subjazem às explicações aparentes" (AGUIAR, 2011, p. 62).

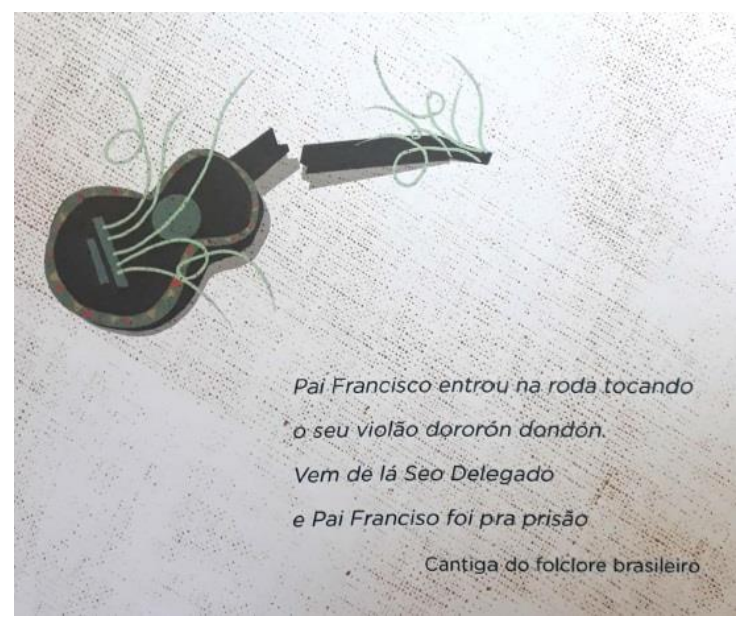

Figura 2 - Epígrafe 
A correspondência entre o Pai Francisco da canção e o da história em questão é garantida também pelas ilustrações, como na página sete (figura 3), em que o pai aparece tocando o mesmo violão que estava com as cordas arruinadas no início do livro. $\mathrm{O}$ violão funciona como um ponto de referência no sequenciamento das imagens, assegurando a coesão entre os elementos, o que mostra, em acordo com Camargo (1995), que as imagens têm também um funcionamento semelhante ao linguístico no que diz respeito à progressão, coesão e coerência.

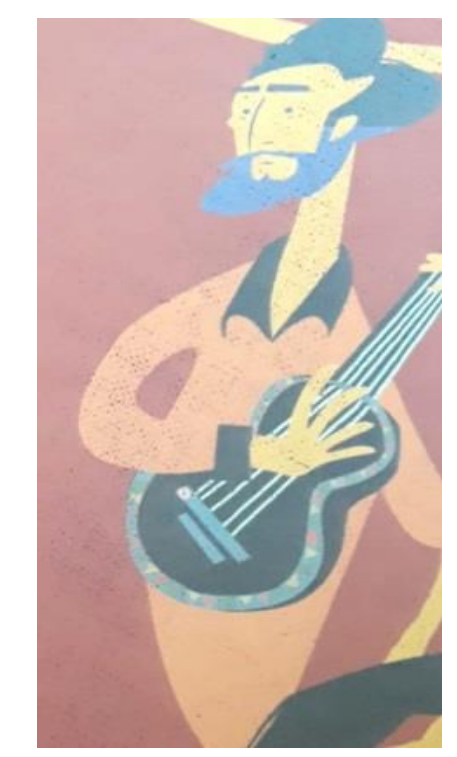

Figura 3 - Pai Francisco tocando violão

Logo no início da narrativa, o protagonista assume para si a tarefa de narrar a história. $\mathrm{O}$ fato de não ser um adulto quem narra a história é fundamental, pois assegura que a perspectiva valorizada seja a da criança. Mais que isso, a narração em primeira pessoa possibilita ao leitor projetar-se no lugar daquela criança e viver com mais facilidade uma experiência de empatia. Indo além, parece-nos importante também que não seja nem mesmo o pai o responsável por contar a história. Além da valorização da visão da criança, podemos pensar que Pai Francisco não está em condições (sociais) de falar; sua voz está interditada e seu discurso encarcerado junto com ele.

Na abertura ainda, o filho indaga à mãe o porquê de o pai estar preso: “- Mãe, cadeia não é pra bandido? Meu pai não é bandido, né? Meu pai não está preso não, né? Hein, mãe?... Por que ele tá preso, hein, mãe? Mãe... “(ARAÚJO, 2015, p. 5).

Neste trecho, somos introduzidos a esse filho fazendo uma série de perguntas à sua mãe, querendo entender a situação de seu pai. A criança mostra todas as suas dúvidas, seja para compreender o que significa ir para cadeia, "ser bandido", se o pai é "bandido" ou se ele está preso. 
Dá a impressão, em um primeiro momento, de que o menino não foi informado se seu pai, de fato, está na prisão. Contudo, ao acrescentar "Por que ele tá preso?", ele mostra certeza de saber o paradeiro do pai, e indaga o motivo de o pai estar lá. Relembrando Miranda e Granato (2016), como forma de tanto preservar os filhos do julgamento de outras pessoas quanto de manter neles um ideal de paternidade, é comum que os familiares optem por esconder das crianças o fato de os pais estarem presos ou as razões que conduziram a isso. Esses questionamentos não são respondidos na história, permanecendo em suspenso: como na vida real, essas dúvidas continuam a assombrar os pensamentos.

Em seguida, o narrador-protagonista faz um desabafo. Ele conta que as pessoas na escola já estão cientes de que o pai dele foi preso, e fica implícito que ele sofre algum tipo de desprezo por isso, pois, adiante, ele afirma que não deseja mais ir à escola. Para a criança, a Escola representa um microcosmo da sociedade, e o fato de ele não se sentir acolhido nesse ambiente só evidencia a própria exclusão e preconceito social que são impostos aos familiares de presidiários. "Na escola todo mundo já sabe. Mas eu não ligo, porque nunca liguei pra ninguém de lá mesmo, e todo mundo de lá é chato, e eu não queria ter amigo mesmo, e eu nem quero mais ir pra escola" (ARAÚJO, 2015, p. 7).

Neste trecho, também somos apresentados à visão que o filho possui do pai, a imagem daquele que conhece todas as coisas. Idealizar, fantasiar (ficcionar) a condição do pai é uma maneira de digerir essa dura realidade que lhe foi imposta. Ademais, elaborar uma imagem de pai como aquele que conhece todas as coisas é um ato muito comum entre os filhos, que enxergam nos pais uma fonte de conhecimento, de sustento e de proteção, trazendo esse arranjo familiar para a realidade, via ficção. "Ele sabe de tudo, de todas as coisas que existem no mundo, ele sabe umas mil coisas... Não, acho que ele sabe mais de dez mil coisas, ele sabe infinito" (ARAÚJO, 2015, p. 7).

$\mathrm{Na}$ cena seguinte, o menino narra que, pela constante ausência do pai, acreditava que ele fosse médico. Ao trazer para a narrativa a questão do trabalho, o narrador dá espaço para que se observem as condições socioeconômicas em que se encontra, visto que o pai se situa no outro lado do espectro em relação ao médico. Com efeito, o pai é tudo o que no imaginário social o médico não representa. Nos dizeres de Foucault (1999, p. 316), nem sempre se trata da "natureza criminosa, mas [de] jogos de força que, segundo a classe a que pertencem os indivíduos, os conduzirão ao poder ou à prisão: [...] os forçados, se fossem bem nascidos, 'tomariam assento nos tribunais e aí distribuiriam justiça", simbolizando o encarceramento da pobreza, transfigurada em inimiga da sociedade burguesa. Essa condição de vida será reforçada mais à frente pelas dificuldades de chegar à prisão para visitar o pai. 
Gradativamente (“Quase nem chorei”, "Só chorei um pouquinho", "Então eu aproveitei e chorei agora") ele se abre a respeito de seus sentimentos, sendo o choro uma válvula de escape para suas emoções reprimidas. Assim como afirma que não queria fazer amigos na escola, ele tenta fingir que não precisa chorar, quando, na verdade, quer veementemente externar suas emoções e também fazer amigos. Nesse sentido, as negações desempenham uma função inversa: ao passo que negam ao nível de enunciado, dão a ver uma vontade reprimida de ser aceito, de fazer amigos, de lidar com sofrimentos que o sufocam.

A mãe afirma que o levaria para ver o pai, e que este não gostaria de saber que seu filho não queria ir para a escola. Novamente, a imagem de pai relapso é desconstruída para fazer surgir a representação de um pai que, mesmo preso, não deixa de ser pai, e permanece atento e preocupado com a educação dos filhos. Precisamente ponto central de nossa leitura: o espaço concedido pela literatura para significarmos de uma outra maneira (LAJOLO, 2008) o sentido de um pai estar preso. O pai não é preso, ele está preso: o cárcere é uma condição, um estado, e não uma definição da personalidade de quem está detido.

Destacamos, como contraponto, que este ainda é um lar em que pesa a tradição, sendo a mãe a pessoa responsável pela proteção direta do filho, o que reforça questões concernentes à segregação entre gêneros. Estendendo essa reflexão, podemos dizer que, sendo a mãe a encarregada dos cuidados dos filhos, uma situação como esta (de cárcere) poderia ser ainda mais agravada caso fosse a figura materna a encarcerada. De acordo com o Relatório do Grupo de Trabalho Interministerial sobre a Reorganização e Reformulação do Sistema Prisional Feminino (Secretaria Especial de Políticas para Mulheres, 2008), apenas 20\% das crianças ficam sob a guarda dos pais quando a mãe é presa, enquanto quase $90 \%$ dos filhos de presos homens permanecem sob os cuidados da mãe ${ }^{6}$.

"E agora chega de falar de chatice" (ARAÚJO, 2015, p. 10). É assim que o narradorprotagonista corta a passagem anterior para iniciar a narração da visita ao pai na prisão. Entre as possibilidades de formulação, o termo que emerge é "chatice". Poderia ter escolhido "tristeza" ou “dor", mas ao dizer "chatice" nubla a expressão de seus sentimentos, o que pode ser interpretado como forma de abrandar o próprio conflito, inclusive mudando a direção da história ("agora chega"). Novamente, há a tentativa de evasão, de fuga, que coloca a personagem criança em situação de prisão, de um tipo interno.

\footnotetext{
${ }^{6}$ Disponível em: https://www.conjur.com.br/2011-set-18/maternidade-prisao-delicada-relacao-entre-direitos-criancalei. Acesso em 23 jun. 2019.
} 
A jornada para visitar o pai reforça as condições em que se encontram mãe e filho. Por exemplo, para visitá-lo, eles precisam tomar um ônibus e depois outro e fazer uma viagem interminável: "Andamos, andamos e nunca chegava. Pegamos um ônibus, outro ônibus, dormi, acordei, dormi e acordei. Passei frio, calor, frio e calor" (ARAÚJO, 2015, p. 11). Isso revela as dificuldades encontradas pelas famílias (pobres) de presos que são obrigadas a se deslocar com uma série de inconveniências, o que por si só já pode dificultar a manutenção do convívio familiar.

Ao chegar lá, surpresa: “Quando chegamos lá, foi muito legal, tinha muita gente na fila, eu fiquei brincando com as outras crianças, e achei bom, porque elas também tinham o pai lá, o outro tinha um irmão e o outro tinha o tio..." (ARAÚJO, 2015, p. 11). O menino se sente acolhido na prisão, porque encontra lá crianças na mesma situação que a sua, fazendo perceber que ele não estava sozinho. Identificando-se com as demais crianças, em situação igual ou semelhante à sua, a personagem consegue sentir conforto por saber que existe outra opção além da solidão que ele fingia ser quista.

E então o momento de clímax: o reencontro. Ao ver o pai, o pequeno se agita, pula para os braços dele, externalizando todas as emoções reprimidas. E, por fïm, o abraço, símbolo do vínculo, da intimidade, do amor paternal e filial. Nesse momento, o pai chora. É a vez de o adulto assumir seu lugar de fragilidade, sem medo de manifestar abertamente a sua própria angústia e emoção, invertendo a relação naturalizada de que a criança é frágil e o adulto deve demonstrar força e impor medo. "Nossa, quando vi meu pai, fiquei pulando pra ele me pegar logo e eu ficar altão. Ele me levantou daquele jeito e me abraçou e chorou, sendo que eu estava tão feliz!" (ARAÚJO, 2015 p. 12).

Avançando para o desfecho, ficamos sabendo que algum tempo já havia se passado desde aquela visita. O menino afirma que, mesmo triste, já não chora mais ("tem dia que eu estou um pouco triste - só um pouco -, mas não choro" (ARAÚJO, 2015, p. 14)). A impressão é a de que ele está superando o conflito, buscando esperanças. O pai havia plantado essa semente de confiança, dizendo que logo voltaria para casa. A mãe, por sua vez, aparece como aquela que chama o filho para a realidade, para o fato de que certamente o pai não virá tão cedo assim. Mas o menino precisa de ficção: "Mas ele gosta de fazer surpresas pra mim" (ARAÚJO, 2015, p.14). E como não precisaria?

Começa então a conjecturar sobre o futuro ao lado do pai, prevendo as diversões que teriam junto, e as coisas que o pai poderia ensinar-lhe. O fato de o pai estar preso não diminui, na ótica do filho, a sua qualidade de pai. A criança é capaz de separar aquilo que o pai faz daquilo que é, sem ligar diretamente seu crime a alguém defeito em sua personalidade, enxergando no homem 
desaprovado socialmente o mais incrível dos pais. Como a própria autora afirma na "primeira orelha": "Isso faz de uma criança um filho". "Aí nos vamos jogar bola. Eu sou o melhor do nosso time e ele é o único que sabe tirar a bola do telhado, e prometeu que vai me ensinar a subir lá em cimão" (ARAÚJO, 2015, p. 15).

O filho afirma categoricamente: "Meu pai tem que vir logo, porque todo mundo fica me falando pra comer salada pra crescer. Mas eu não posso crescer agora, preciso esperar meu pai” (ARAÚJO, 2015, p. 15). Modalizando o enunciado de forma imperativa, o protagonista está projetando ali todo seu desejo e necessidade de ter o pai de volta em casa, em sua vida cotidiana. Não querer crescer aparece como um efeito da ausência do pai: ambos, filho e pai, encontram-se aprisionados. Em outras palavras, a liberdade do filho é afetada pela prisão do pai. Podemos ler nessa passagem também que não querer crescer é uma forma de se manter intacto na memória do pai, expondo um receio de ser esquecido e também um receio de esquecer.

Por fim, serão as ilustrações que darão um fecho para a história. Paralelamente à narração verbal, em todas as páginas à esquerda, há imagens do menino fazendo uma refeição (figura 4, 5 e 6), sem nunca tocar na salada. Ao final, como vimos, fica explicado o motivo disso: como era dito que a salada faria com que ele crescesse, ele decida não comê-la. Contudo, na contracapa (figura 7), o prato está completamente vazio. Lemos isso como a superação do conflito, a possibilidade vislumbrada pelo filho de viver um relacionamento outro (diferente) com o pai, ciente dos obstáculos sociais aí implicados. Ainda que a narração verbal já tivesse sido encerrada, as imagens seguem contando a história, inclusive na parte final da encadernação, levando ao máximo o alcance significativo da narrativa, que só então é concluída, ou melhor, interrompida em sua narração.

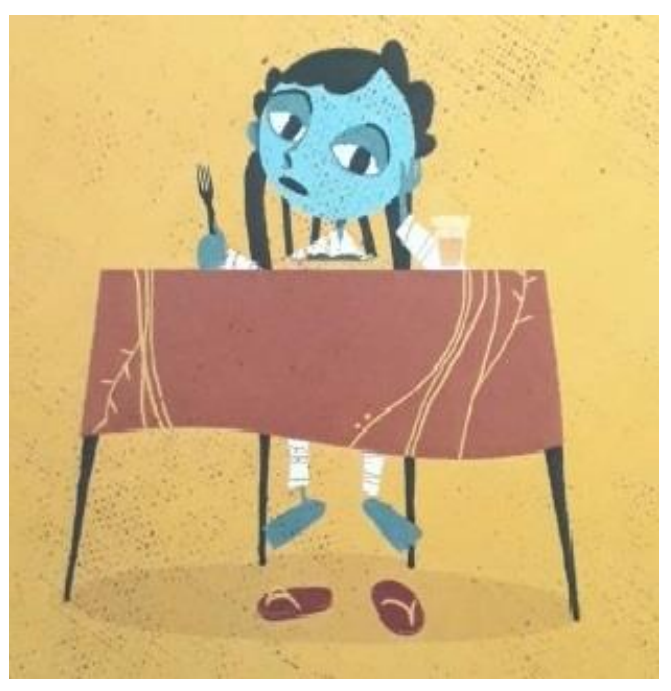

Figura 4 - O filho evitando a refeição 
Revista Água Viva

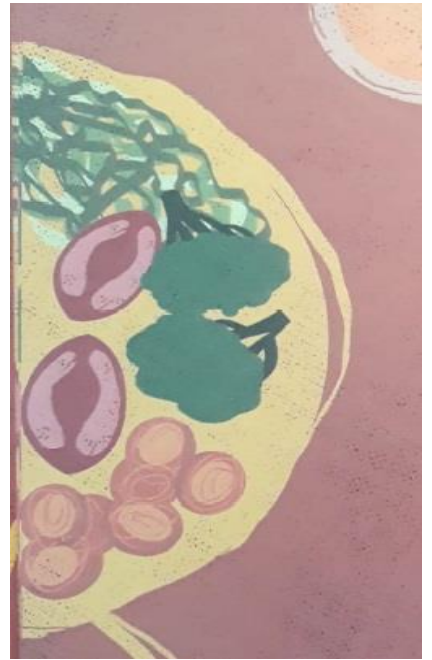

Figura 5 - Salada deixada no prato

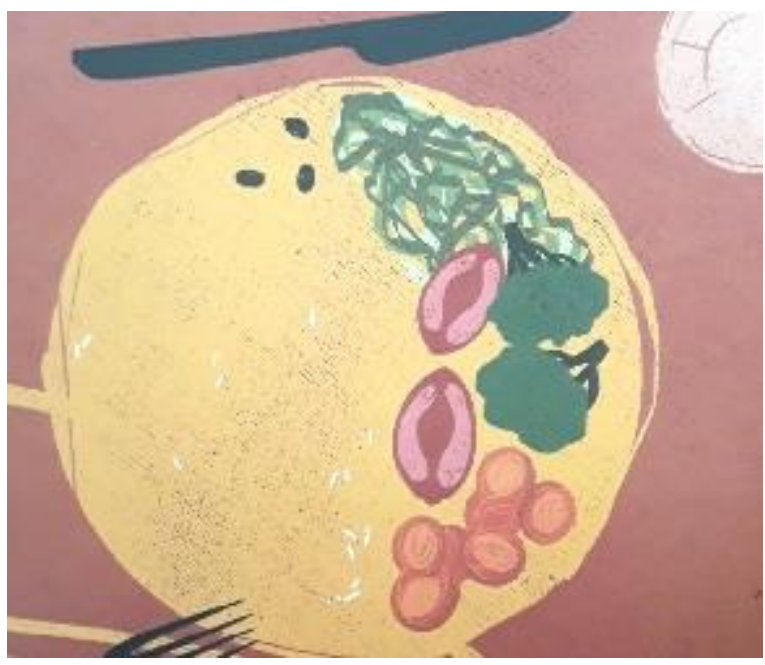

Figura 6 - Ainda salada deixada no prato 


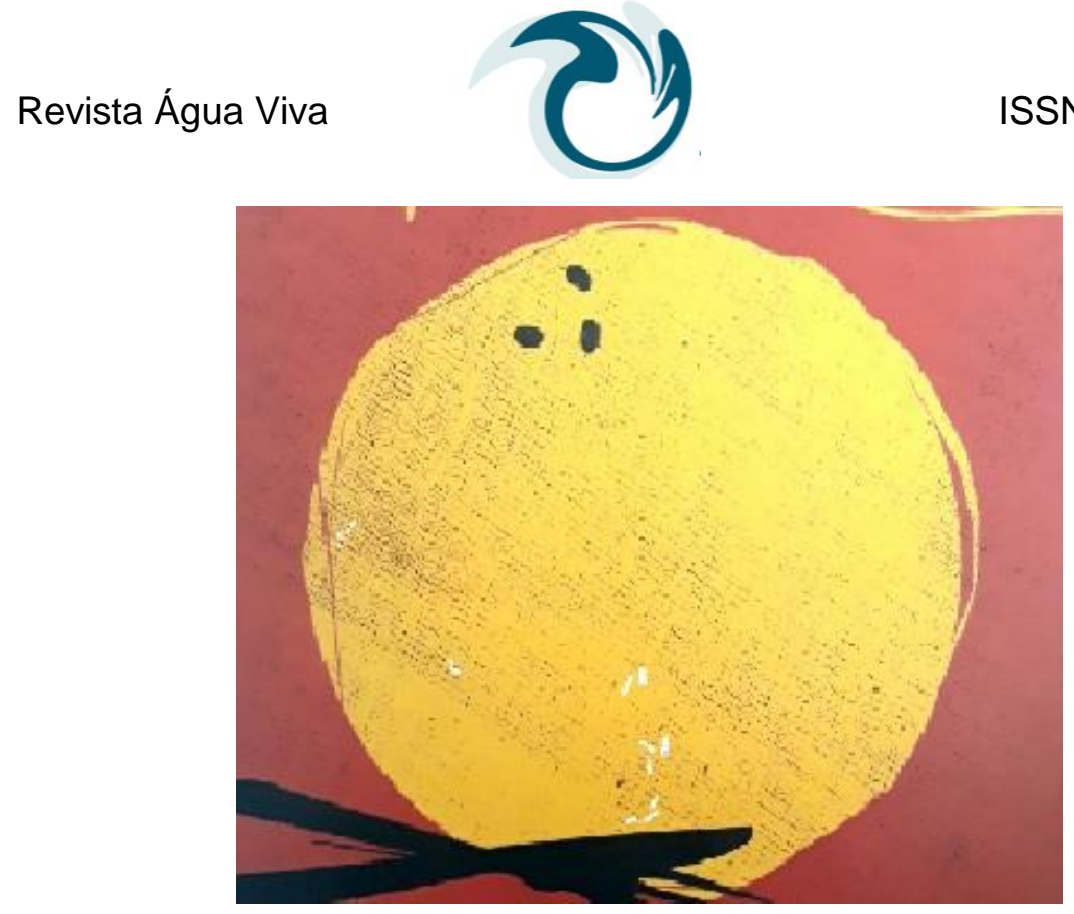

Figura 7 - Contracapa - O prato vazio

\section{A visita acaba... o cárcere, não}

Esta foi apenas uma visita a Pai Francisco. Não sendo possível esgotar a profundidade do assunto, contentamo-nos em expor a complexidade de um tipo de relação familiar que merece ser compreendido e respeitado, entendendo que o aprisionamento dos pais pode trazer consequências para a vida dos filhos, o que significa que não é pertinente simplificar e reduzir essa experiência como uma forma menos importante de exercer e viver o amor na célula familiar. Terminada a visita, a família vai embora, mas algo dela fica na prisão: o pai permanece lá. A despedida é temporária, mas não é garantia de que o próximo encontro será em liberdade.

Em Pai Francisco, a singularidade da experiência paterna em estado de cárcere, e também a singularidade da experiência de ser filho de um pai em encarcerado, surge como uma forma de ser pai/filho entre tantas outras; e uma forma que precisa ser estudada, compreendida, e não descartada de antemão. O olhar do filho para o pai que está preso vai além da prisão, e enxerga além do encarceramento. Mesmo preso, aquele homem continua a ser pai e pode (inclusive com respaldo da lei) manter uma convivência afetiva saudável com seus filhos.

Fica evidente a importância de a literatura trabalhar assuntos delicados com o leitor infantil, como forma de colocá-lo em contato com realidades com as quais não está familiarizado, ou, ao contrário, com situações que vive e que jamais são retratadas. Não faria sentido, obviamente, tratar de qualquer assunto de qualquer forma; daí a latente preocupação com a linguagem, seja verbal, imagética ou outra. A Literatura infantil, mesmo na condição de ficção, deve se preocupar em 
(in)formar a criança em um mundo de experiências múltiplas, sem silenciar histórias possíveis, histórias vividas de verdade.

\section{REFERÊNCIAS}

AGUIAR, V. T. A literatura infantil e juvenil faz história. In: MARTHA, A. A. P (org.). Tópicos de literatura infantil e juvenil. Maringá: EDUEM, p. 51-70, 2011.

ARAÚJO, M. M. Pai Francisco. Ilustração de Marcus Vinícius Vasconcelos. São Paulo: Polém, 2015.

BRASIL. Lei de execução Penal. Lei no. 7.210, de 11 de julho de 1984. República Federativa do Brasil, Brasília, DF, 1984. Disponível em: http://www.planalto.gov.br/ccivil_03/leis/17210.htm. Acesso em 21 jun. 2019.

BRASIL. Lei no 8.069, de 13 de julho de 1990. Dispõe sobre o Estatuto da Criança e do Adolescente e dá outras providências. Diário Oficial da República Federativa do Brasil, Brasília, DF, 1990. Disponível em: https://www2.camara.leg.br/legin/fed/lei/2014/lei-12962-8-abril-2014-778440publicacaooriginal-143816-pl.html. Acesso em 21 jun. 2019.

CAMARGO, L. Ilustração do livro infantil. Belo Horizonte: Lê, 1995.

COSTA, M. M. A narrativa infantil brasileira. In: MARTHA, A. A. P (org.). Tópicos de literatura infantil e juvenil. Maringá: EDUEM, p. 101-122, 2011.

DEPEN. Departamento Penitenciário Nacional. 2016. Disponível em: depen.gov.br/DEPEN/noticias-1/noticias/infopen-levantamento-nacional-de-informacoespenitenciarias-2016/relatorio_2016_22111.pdf. Acesso em 19 jun. 2019.

FOUCAULT, M. A verdade e as formas jurídicas. Trad. de Eduardo Jardim e Roberto Machado. Rio de Janeiro: Editora Nau, 2005.

FOUCAULT, M. Vigiar e punir: história da violência nas prisões. 20 ed. Trad. de Raquel Ramalhete. Petrópolis: Vozes, 1999.

GRANJA, R.; CUNHA, M. P.; MACHADO, H. Formas alternativas do exercício da parentalidade: paternidade e maternidade em contexto prisional. Ex aеquo, 28, p. 73-96, 2013.

LAJOLO, M. Do mundo da leitura para a leitura de mundo. 6 ed. São Paulo: Ática, 2008.

MARTHA, A. A. P. Literatura infantil e juvenil: concepções introdutórias. In: (org.). Tópicos de literatura infantil e juvenil. Maringá: EDUEM, p. 15-24, 2011.

MIRANDA, M. L. A.; GRANATO, T. M. M. Pais encarcerados: narrativas de presos sobre a experiência da paternidade na prisão. Psico (Porto Alegre), v. 47, n.4, p. 309-318, 2016. 